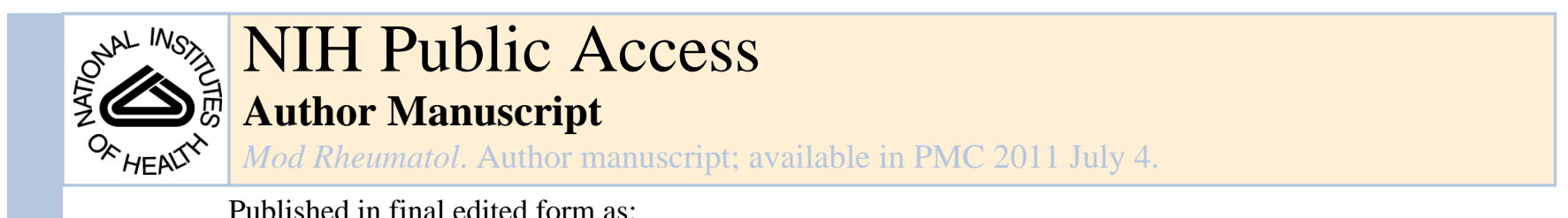

Published in final edited form as:

Mod Rheumatol. 2010 April ; 20(2): 114-122. doi:10.1007/s10165-009-0251-4.

\title{
Adenosine in fibrosis
}

\author{
Edwin S. L. Chan and Bruce N. Cronstein \\ Clinical and Translational Science Institute, NYU School of Medicine, 550 First Ave., New York, \\ NY 10016, USA
}

Bruce N. Cronstein: bruce.cronstein@nyumc.org

\begin{abstract}
Adenosine is an endogenous autocoid that regulates a multitude of bodily functions. Its antiinflammatory actions are well known to rheumatologists since it mediates many of the antiinflammatory effects of a number of antirheumatic drugs such as methotrexate. However, inflammatory and tissue regenerative responses are intricately linked, with wound healing being a prime example. It has only recently been appreciated that adenosine has a key role in tissue regenerative and fibrotic processes. An understanding of these processes may shed new light on potential therapeutic options in diseases such as scleroderma where tissue fibrosis features prominently.
\end{abstract}

\section{Keywords}

Adenosine receptor; Fibrosis; Collagen; Cirrhosis

\section{Introduction}

Adenosine is a potent physiologic and pharmacologic regulator. Adenosine was first recognized as a physiologic regulator of coronary vascular tone by Drury and Szent-Gyorgy in 1929 [1]. However, it was not until 1970 that Sattin and Rall [2] showed that adenosine regulates cell function via occupancy of specific receptors on the cell surface. It is now clear that there are at least four different subtypes of adenosine receptors, any one or combination of which may be expressed on cell surfaces (recently reviewed in [3]). All four adenosine receptors have been cloned, and the deduced sequence reveals that all four are members of the large family of 7-transmembrane spanning, $G$ protein coupled receptors. Three of the adenosine receptor subtypes, $\mathrm{A}_{1}, \mathrm{~A}_{2 \mathrm{~A}}$, and $\mathrm{A}_{2 \mathrm{~B}}$, are highly conserved throughout evolution (80-95\% sequence homology), whereas $A_{3}$ receptors vary significantly among species. In general, $\mathrm{A}_{1}$ receptors are coupled to pertussis toxin-inhibited Gi-coupled signal transduction proteins or directly to ion channels, whereas $A_{2}$ receptors $\left(A_{2 A}\right.$ and $\left.A_{2 B}\right)$ are coupled to

\footnotetext{
(C) Japan College of Rheumatology 2009

Correspondence to: Bruce N. Cronstein, bruce. cronstein@nyumc . org.

Conflict of interest statement Dr. Cronstein has patents on the use of adenosine A2A receptor agonists to promote wound healing, the use of adenosine $\mathrm{A}_{2} \mathrm{~A}$ receptor antagonists for the treatment of fibrosis, the use of adenosine $\mathrm{A}_{1}$ receptor antagonists to treat osteoporosis and other bone diseases, the use of adenosine $\mathrm{A}_{1}$ and $\mathrm{A}_{2} \mathrm{~B}$ receptor antagonists to treat fatty liver, and the use of adenosine $\mathrm{A}_{2 \mathrm{~A}}$ receptor agonists to treat prosthesis loosening. During the past 2 years Dr. Cronstein has consulted for the following companies(<US \$10,000): Cephalon, Cypress Bioscience, Inc., King Pharmaceutical (licensee of patents above), CanFite Biopharmaceuticals, Bristol-Myers Squibb, Cellzome, Takeda Pharmaceuticals, Prometheus Laboratories, Re-generon (Westat, DSMB), Sepracor, Amgen, Endocyte, Protalex, Allos, Inc., Combinatorx, Kyowa Hakka, Hoffman-LaRoche, Savient, and Avidimer Therapeutics. Dr. Cronstein owns equity in CanFite Biopharmaceuticals and has received grants from the National Institutes of Health, King Pharmaceuticals, and the Vilcek Foundation. Dr. Cronstein is on the board of directors of the Vilcek Foundation. Dr. Edwin Chan holds a patent on the use of adenosine $\mathrm{A}_{2} \mathrm{~A}$ receptor antagonists for use in fibrosis.
} 
$\mathrm{G}_{\alpha \mathrm{S}}$-linked signaling molecules and stimulate adenylyl cyclase and cyclic adenosine monophosphate (cAMP) accumulation. Adenosine receptors or receptor-mediated effects have been demonstrated in virtually every tissue or organ examined. Some of the more prominent physiologic or pharmacologic effects mediated by adenosine receptors include: neurotransmission $\left[\mathrm{A}_{1}\right.$ and $\mathrm{A}_{2 \mathrm{~A}}$ receptors; the central nervous system (CNS) effects of caffeine are thought to result from adenosine receptor antagonism]; modulation of cardiac conduction $\left(A_{1}\right.$ receptors; intravenous boluses of adenosine are widely used for the treatment of supraventricular tachycardia); coronary vasodilation $\left(\mathrm{A}_{2 \mathrm{~A}}\right.$ receptors; infusions of adeno-sine are licensed for clinical use as a coronary vasodilator for pharmacologic stress testing); regulation, indirectly, of airway tone ( $\mathrm{A}_{1}$ and $\mathrm{A}_{2 \mathrm{~B}}$ receptors); and inhibition of inflammation (in part mediating the anti-inflammatory effects of low-dose methotrexate, the most commonly used disease-modifying antirheumatic drug for the treatment of rheumatoid arthritis) (reviewed in [4-6]). It has been demonstrated that adenosine modulates neutrophil function via interaction with $A_{1}$ and $A_{2}$ receptors and, when released from cells in increased concentrations, inhibits inflammation (reviewed in [5]). In many tissues and cell types, $A_{1}$ and $\mathrm{A}_{2 \mathrm{~A}}$ receptors have opposing actions not only on cAMP levels but on function as well (cf. [7-9]). More recently we have demonstrated that topical application of an adenosine $\mathrm{A}_{2 \mathrm{~A}}$ receptor agonist promotes wound healing, a process dependent upon the proliferation of blood vessels and increased matrix formation, in both normal mice and diabetic rats [9-11].

\section{Adenosine in inflammation}

Inflammation is a homeostatic response to tissue injury, and the resolution of inflammation is generally tightly linked to matrix regeneration. Many of the growth factors that play a role in tissue repair and regeneration also possess anti-inflammatory activity; the best known of these is transforming growth factor-beta (TGF- $\beta$ ), which is a powerful anti-inflammatory mediator and potent stimulus for tissue regeneration. Our prior work and that of others clearly demonstrates that adenosine plays a role parallel to that of TGF- $\beta$ in regulating the transition from inflammation to matrix and tissue regeneration.

The anti-inflammatory effects of adenosine were first suggested by our observation that adenosine, acting at a site on the surface of the neutrophil, inhibits stimulated neutrophil generation of superoxide anion [12]. Subsequent pharmacological studies from our laboratory [13] and others [14] revealed that the effects of adenosine were mediated by interaction with a specific cell surface receptor (formerly the $A_{2}$ receptor, now clearly identified as the $\mathrm{A}_{2 \mathrm{~A}}$ receptor). That endogenously released adenosine could diminish inflammation was first demonstrated in our studies of neutrophils [12] and later confirmed in our laboratory using a model of neutrophil-mediated vascular injury [15]. Rosengren and colleagues first reported that endogenously generated adenosine acting at its receptors exercised a tonic suppressive effect on inflammation in vivo [16], and Ohta and Sitkovsky [17] expanded on this finding by identifying adenosine, acting at $\mathrm{A}_{2 \mathrm{~A}}$ receptors, as the endogenous signal terminating acute inflammation in several models of inflammation. Endogenously released adenosine clearly diminishes reperfusion injury in a variety of different animal models [18-20] and also inhibits atherosclerosis in an in vivo model [21].

Most of the anti-inflammatory effects of adenosine are mediated via $\mathrm{A}_{2 \mathrm{~A}}$ and $\mathrm{A}_{3}$ receptors. Adenosine, via inter-action with $\mathrm{A}_{2 \mathrm{~A}}$ receptors, inhibits stimulated neutrophil adhesion, generation of toxic oxygen metabolites, phagocytosis, and neutrophil-mediated cell injury $[7,12,13,22]$. Adenosine, most likely acting at $\mathrm{A}_{2 \mathrm{~A}}$ receptors, also inhibits lymphocyte proliferation and induces suppressor function and phenotype [23-34]. Occupancy of adenosine $\mathrm{A}_{2 \mathrm{~A}}$ receptors on monocytes inhibits cytokine production [tumor necrosis factoralpha (TNF- $\alpha$ ), interleukin (IL)-6, IL-8, and IL-12] and enhances release of the anti-inflammatory cytokine IL-10 $[14,17,32,35-40]$. Adenosine, acting at $A_{2}$ receptors (probably 
originally misidentified as $\mathrm{A}_{2 \mathrm{~B}}$ receptors), inhibits inhibitory- $\kappa \mathrm{B}(\mathrm{I} \kappa \mathrm{B})$ kinase and nuclear factor- $\kappa \mathrm{B}(\mathrm{NF} \kappa \mathrm{B})$ translocation to the nucleus, a central step in the pathogenesis of inflammation [41, 42]. In murine cells $A_{3}$ receptors also downregulate inflammatory cytokine secretion. Adenosine, acting at $\mathrm{A}_{2 \mathrm{~B}}$ receptors, inhibits synoviocyte collagenase production without affecting production of either stromelysin or tissue inhibitor of metalloprotease [43]. Various adenosine receptor agonists are anti-inflammatory in animal models. Interestingly, in in vivo studies, $\mathrm{A}_{1}$ adenosine receptor agonists were found to be the most anti-inflammatory, and other studies have suggested that the anti-inflammatory effects of $\mathrm{A}_{1}$ receptor agonists are mediated through the CNS and CNS-stimulated adenosine release in inflamed tissues [44]. More recent studies also suggest a role for peripheral $\mathrm{A}_{1}$ receptors, most probably on monocyte/macrophages, in suppression of inflammation in the lung. It is unclear how $\mathrm{A}_{1}$ receptors mediate this effect in this animal model of adenosine deaminase deficiency, but in the absence of $A_{1}$ receptors there is a significant increase in pulmonary content of chemotactic and growth factors for eosinophils [45].

In general, the role of adenosine as a regulator of inflammation has been established in models of acute inflammation, but adenosine, acting at its receptors, modulates chronic inflammation and adaptive immune responses as well. In particular, adenosine $\mathrm{A}_{2 \mathrm{~A}}$ receptors on dendritic cells diminish the capacity of these cells to promote Th1-type responses [46] and diminish monocyte production of IL-12 [39, 40, 47], a central promoter of Th1 immunologic responses. Adenosine, acting through its receptors, also modulates T cell responses to antigen $[32,46,48,49]$. Our laboratory has previously reported that adenosine $A_{1}$ receptors promote and adenosine $A_{2 A}$ receptors inhibit fusion of human peripheral blood mono-cytes to form giant cells, although the role of adenosine $\mathrm{A}_{1}$ receptors in granuloma formation has not been well studied [50].

\section{Wound healing}

Based on preliminary evidence that adenosine $\mathrm{A}_{2 \mathrm{~A}}$ receptor agonists enhanced migration of fibroblasts and endothelial cells into artificial wounds, we first examined the fibro-genic effects of adenosine in an in vivo model of excisional wound healing. Topical application of an adenosine $\mathrm{A}_{2 \mathrm{~A}}$ receptor agonist, CGS-21680, significantly enhanced excisional wound closure in this model, with $50 \%$ wound closure achieved by day 2, compared with day 6 in untreated control BALB/c mice [9]. Another adenosine A2A receptor agonist, MRE0094, was similarly effective in promoting excisional wound closure in BALB/c mice, its effects more rapid than recombinant human platelet-derived growth factor (becaplermin gel), an agent marketed for use in diabetic ulcers [11]. Promotional effects of CGS-21680 on wound closure were also seen in rats rendered diabetic following injection of streptozotocin [9].

\section{Pulmonary fibrosis}

Pulmonary fibrosis is an important component of many interstitial lung diseases. The involvement of adenosine in pulmonary fibrosis is perhaps unsurprising considering its involvement in many other pulmonary diseases and that adenosine levels are elevated in humans with diseases such as asthma and chronic obstructive pulmonary disease [51, 52]. Furthermore, murine models of these pulmonary disorders as well as murine idiopathic pulmonary fibrosis displayed similar changes in adenosine [53-55]. The induction of fibrotic changes in the lungs, much as elsewhere, takes place over a substantial period of time and under the influence of a host of profibrotic cytokines, growth factors, and other tissue mediators. One of these recently highlighted is interleukin-13 (IL-13), and trans-genic IL-13 has also been identified to have potent fibro-genic effects in a variety of tissues including both lung and liver [56-59]. Blackburn et al. [53] first reported a vast increase in adenosine levels in the lungs of IL-13 trans-genic mice, and this elevation was associated 
with a sig-nificant suppression of the activity of adenosine deaminase, a major catabolizing enzyme of adenosine. In concert with the anticipated effects of IL-13, these mice developed substantial subepithelial airway fibrosis histologically, along with marked elevation in pulmonary collagen content. Interestingly, the fibrotic phenotype was reversed by administration of pegylated adenosine deaminase therapy, thereby reversing the IL-13induced tissue elevation in adenosine. This was one of the earliest demonstrations of the importance of adenosine in mediating organ fibrosis.

Blackburn's group substantiated these findings by studying a murine model of high tissue adenosine, adenosine deaminase-deficient mice. These mice were developed in their laboratory, and targeted gene deletion resulting in the deficiency of a key enzyme that catabolizes adenosine into inosine renders both circulating and tissue adenosine levels extremely high $[60,61]$. One of the potential benefits of using this model is that adenosine deaminase enzyme therapy can be administered by injection to these mice, much as it is used as therapy for adenosine deaminase in humans, thus enabling direct manipulation of tissue adenosine levels through varying the dose of adenosine deam-inase injected. Furthermore, induction of fibrosis in this model is spontaneous and does not require administration of exogenous chemical agents, or genetic manipulation as has been employed by most other in vivo models of tissue fibrosis. Thus, any changes observed are directly attributable to changes in tissue adenosine itself. In mice completely deficient for adenosine deaminase, mortality from lung disease arose within a few weeks of birth, and these mice did not live long enough to develop significant pulmonary fibrosis [62]. The use of an adenosine deaminase minigene expressed in the upper gastrointestinal tract allowed for the creation of a new line of animals only partially deficient for adenosine deaminase, and adenosine deaminase is not expressed in tissues outside the gastrointestinal tract [63]. These animals are able to live for up to 5 months and develop a number of pulmonary pathologies, including fibrosis, and die from apparent respiratory distress. Using this partially adenosine deaminase-deficient mouse model, the authors were able to show that elevation of adenosine in this model was associated with increases in the transcript levels of a number of profibrotic mediators that included TGF- $\beta 1$, IL-1 $\beta$, IL-13, plasminogen activator inhibitor-1 (PAI-1), and osteopontin. Significant elevations in transcript levels of adenosine $A_{1}$ and $A_{2 B}$ receptors were also reported [64]. These changes correlated with histo-logically demonstrable fibrosis with an increased number of pulmonary myofibroblasts and collagen deposition following staining with Masson's trichrome as well as semi-quantitative assessment of fibrosis by Ashcroft's fibrosis scoring system [60, 64]. Excessive collagen deposition was not limited to the lungs, but was also seen in the liver and kidney glomeruli. All of these profibrotic effects of adenosine were reversed by administration of high-dose adenosine deaminase. Despite partial enzyme replacement therapy in this model, elevation of adenosine levels was still evident along with histological evidence of pulmonary fibrosis. These observations were later confirmed in a model of IL-4-induced pulmonary fibrosis in C57BL/6 mice [54].

Generation of adenosine in the extracellular milieu relies on one of two main sources: intracellular adenosine that is transported out of the cell, and the dephosphoryla-tion of AMP by the enzyme 5'-nucleotidase (CD73) or alkaline phosphatase, which can in turn be dephosphoryl-ated from adenosine triphosphate (ATP) or adenosine diphosphate (ADP) by ectonucleoside triphosphate di-phosphohydrolase 1 (CD39) or alkaline phosphatase [65-67]. Thus, deletion of CD73 or CD39 eliminates one of the major routes of adenosine formation, and gene deletion in mice provides a model of low tissue adenosine.

Using the CD73-deficient mouse model, Volmer et al. challenged animals with injections of bleomycin, a well-known fibrogenic stimulant for both lung and skin. Pulmonary adenosine levels increased by threefold following bleomycin challenge in wild-type mice compared 
with controls injected with saline, along with a concomitant increase in membrane AMPase [55]. This increase in adenosine that results from bleomycin administration was dependent on CD73, since CD73-deficient animals did not exhibit the same adenosine accumulation. While injection of bleomycin was associated with an increase in pulmonary a-1 procollagen transcript, collagen protein, and histolog-ical fibrosis, as well as transcript levels of proinflammatory and profibrotic mediators IL- $1 \beta$, TNF- $\alpha$, TGF- $\beta 1$, PAI- 1 , and osteopontin, loss of CD73 was associated with exacerbation of bleomycin-induced pulmonary injury. Restoration of AMPase activity by intranasal administration of exogenous nucleotidase conjugated to polyethylene glycol (PEG) resulted in a reduction of both inflammation and fibrosis in this model, along with elevation in pulmonary adenosine levels.

Among the four known adenosine receptors, the $A_{2 B}$ receptor is known to possess the ability to induce differentiation of pulmonary fibroblasts into myofibroblasts [68]. Expression of $\mathrm{A}_{2 \mathrm{~B}}$ receptors is increased in the lungs of adenosine deaminase-deficient mice [63]. Using a novel $A_{2 B}$ receptor antagonist, Sun et al. [69] were able to show that accumulation of myofibroblasts and $\alpha$-smooth muscle actin staining in adenosine deaminase-deficient mice were reduced by $\mathrm{A}_{2 \mathrm{~B}}$ receptor antagonist treatment. This was accompanied by a reduction in collagen deposition in the airways seen on Masson's trichrome staining as well as reversal of the increase in whole-lung a1-procollagen transcript levels and collagen protein levels in bronchoal-veolar lavage fluid seen in control animals. Administration of the $\mathrm{A}_{2 \mathrm{~B}}$ receptor antagonist also suppressed production of the profibrotic mediators, TGF- $\beta 1$, and osteopontin by alveolar macrophages. This protective effect of $\mathrm{A}_{2 \mathrm{~B}}$ receptor antagonist treatment on pulmonary fibrogenesis was associated with a decrease in inflammatory cells recovered from bronchoalveolar lavage fluid, including alveolar macrophages, lymphocytes, neutrophils, and eosinophils. Treatment with the $\mathrm{A}_{2 \mathrm{~B}}$ receptor antagonist also significantly reduced production of cytokines and chemokines including TNF- $\alpha$, IL-6, chemokine (C-C motif) ligand 11 (CCL11), CCL17, chemokine (C-X-C motif) ligand 1 (CXCL1), and CXCL2. Alveolar airspace enlargement akin to that seen in emphysema, present in adenosine deaminase-deficient control animals, was als prevented by $\mathrm{A}_{2 \mathrm{~B}}$ receptor antagonist treatment, along with normalization of the increase in metalloproteases and inhibitors of proteases, tissue inhibitor of metalloprotein-ase-1 (TIMP-1), matrix metalloproteinase (MMP)-9, and MMP-12, seen in control mice. To verify the effect of $A_{2 B}$ receptor antagonism on the protection of development of pulmonary fibrosis, the authors also examined $\mathrm{A}_{2 \mathrm{~B}}$ receptor antagonist treatment in the bleomycin-induced pulmonary fibrosis model. Whereas intratracheal administration of bleomycin induced myofibroblast differentiation, collagen deposition and production, as well as histological fibrosis in the lungs of experimental animals, $A_{2 B}$ receptor antag-onist treatment reversed all of these. The role of the adenosine $A_{3}$ receptor in murine pulmonary fibrogenesis has also been studied following bleomycin exposure [70]. While levels of TFG- $\beta 1$ message were found to be elevated in whole-lung extracts and bronchoalveolar lavage fluid cell pellets of $\mathrm{A}_{3}$ receptordeficient mice, no change in the active form of TFG- $\beta 1$ protein was seen, although reductions in message levels and activities of MMP-9 and TIMP-1 were evident. Little difference in the degree of pulmonary fibrosis was observed between $\mathrm{A}_{3}$ receptor-deficient mice and wild-type control mice following bleomycin exposure. Thus, despite its importance as an anti-inflammatory regulator, the $\mathrm{A}_{3}$ receptor is unlikely to be a key player in the control of fibrogenesis in the lung.

\section{Hepatic fibrosis}

Release of adenosine is an important mechanism responsible for the anti-inflammatory effects of some common antirheumatic drugs, including salicylates, sulfasalazine, and most notably methotrexate $[6,71,72]$. The mechanism of action of methotrexate is complex and may involve folate antagonism as well as polyamine inhibition, although recent data have 
suggested that adenosine release is pivotal to many cellular anti-inflammatory effects of methotrexate not otherwise explainable by alternative mechanisms. One of the most serious and well-documented side-effects of methotrexate therapy is fibrosis of the liver. It is notable that ethanol, one of the most common causes of cirrhosis worldwide, inhibits adenosine uptake via the nucleoside transporter and thereby increases extracellular adenosine levels [73]. This is associated with an increase in intra-cellular cAMP and desensitization of cAMP signaling. It has long been known that, in humans, ethanol consumption is associated with an increase in urinary purine metabolites and turnover of adenine nucleotide pool [74]. Some of the central nervous system hypnotic effects of ethanol are also mediated through adenosine release [75]. It is possible, therefore, that the fibrosing effect of methotrexate in the liver may also be mediated through the release of adenosine. It is worth noting that there has been extensive epidemiologic demonstration of the protective effects of coffee in liver cirrhosis [76, 77]. It is possible that these protective effects may be attributable to caffeine, an effective and nonselective antagonist of adenosine receptors.

The hepatic stellate cell is the principal fibrogenic cell type in the liver [78-81]. Many known soluble stimuli can cause hepatic stellate cell proliferation, activation, differentiation, and subsequently production of fibrous matrix proteins including collagen. We have previously shown that both ethanol and methotrexate induce the release of adenosine from hepatocytes to over threefold baseline levels at pharmacologically relevant levels of these stimuli [82]. The known hepatic fibrosing agents, carbon tetrachloride and thioacetamide, also promote adenosine release from murine liver slices ex vivo. Hepatic adenosine promotes collagen production by stellate cells and at the same time suppresses the expression and activities of the metalloproteinases MMP-9 and MMP-14. These profibrotic actions of adenosine in the liver are mediated through the $\mathrm{A}_{2 \mathrm{~A}}$ receptor, and indeed cirrhotic mouse livers show increased expression of adenosine $A_{2 A}$ receptors. Adenosine $A_{2 A}$ receptor-deficient mice are resistant to the development of hepatic fibrosis following administration of carbon tetrachloride or thioacetamide, as are mice treated with an adenosine $\mathrm{A}_{2 \mathrm{~A}}$ receptor antagonist. Adenosine also inhibits platelet-derived growth factor (PDGF)-induced stellate cell chemotaxis via the $\mathrm{A}_{2 \mathrm{~A}}$ receptor [83]. Activation of the $\mathrm{A}_{2 \mathrm{~A}}$ receptor induces a loss of actin stress fibers in hepatic stellate cells, and endothelin-1 and lyso-phosphatidic acid-mediated stellate cell contraction are diminished [84]. There have also been previous contradictory reports of protective effects of adenosine in carbon tetrachloride-induced cirrhosis in rats [85]. However, adenosine was administered to experimental animals intraperitoneally only three times a week in this model. Since adenosine has an extremely short half-life in blood and tissues of less than $10 \mathrm{~s}$, much as adenosine administered as an intravenous bolus to patients with supraven-tricular tachyarrhythmias has a very short-lasting effect amounting to seconds, it is difficult to be able to attribute the reported protective effects directly to adenosine itself.

Upregulation of collagen production by adenosine involves at least two of the principal subtypes of collagen seen in the fibrotic liver, collagen types I and III [86]. Interestingly, signal transduction mechanisms for the two collagen subtypes appear to be different. While production of collagen type I is regulated by protein kinase A, src, and extracellular signalregulated kinase (ERK), collagen type III is dependent upon p38 mitogen-activated protein kinase (MAPK). These results were confirmed both by pharmacologic inhibition and small interfering RNA-mediated knockdown of the respective signaling molecules.

\section{Dermal fibrosis}

Since activation of the adenosine $\mathrm{A}_{2 \mathrm{~A}}$ receptor increases matrix synthesis in wounds and promotes wound healing, it is no surprise that adenosine also has an important role in the development of more diffuse dermal fibrosis (Fig. 1). $\mathrm{A}_{2 \mathrm{~A}}$ receptor occupancy stimulates the 
production of collagen types I and III by human dermal fibroblasts, an effect associated with an increase in ERK phosphorylation [87]. Suppression of the expression and activities of metallo-proteases, MMP-9 and MMP-14, but not MMP-2, is also observed with $\mathrm{A}_{2 \mathrm{~A}}$ receptor activation. Pharmacologic inhibition of MEK-1, an upstream activator of ERK, mitigates the stimulating effect of $\mathrm{A}_{2 \mathrm{~A}}$ receptor occupancy on collagen production. Adenosine $\mathrm{A}_{2 \mathrm{~A}}$ receptor-deficient mice or $\mathrm{C} 57 \mathrm{BL} / 6$ mice treated with an $\mathrm{A}_{2 \mathrm{~A}}$ receptor antagonist are both protected against bleomycin-induced dermal fibrosis, a murine model of scleroderma, with reductions in skin thickness and tensile strength, a decrease in total hydroxyproline content, and histological reduction in fibrous tissue in the skin following staining with picrosirius red. The $\mathrm{A}_{2 \mathrm{~A}}$ receptor-mediated fibrosing effect in the skin may be due in part to more avid recruitment of fibrocytes into the skin [88].

Adenosine deaminase-deficient mice, described above and whose adenosine levels in the skin is vastly elevated at around 12 -fold that of control mice, spontaneously develop dermal fibrosis with increased dermal collagen content even in the absence of bleomycin or any other inciting fibrosing stimuli [61]. The development of dermal fibrosis in these mice is diminished by administration of an $\mathrm{A}_{2 \mathrm{~A}}$ receptor antagonist, again confirming the role of the $\mathrm{A}_{2 \mathrm{~A}}$ receptor in mediating fibrogenesis in the skin. Dermal fibrogenesis in adenosine deaminase-deficient mice is associated with elevations of a number of key profibrotic mediators, including TGF- $\beta 1$, connective tissue growth factor (CTGF), PDGF-AA, IL-13, and IL-6.

\section{Adenosine in fibrosis elsewhere in the body}

The cardiac fibroblast, as a key producer of matrix proteins in the heart, is an important participant in cardiac remodeling whether as part of the normal ageing process or as a result of long-standing hypertension, after myocardial infarction, or in hypertrophic conditions such as hypertrophic obstructive cardiomyopathy. Cardiac fibroblasts synthesize adenosine, and fibroblast-derived adenosine inhibits fetal calf serum-induced growth of atrial and left ventricular rat fibroblasts via activation of adenosine $A_{2 B}$ receptors $[89,90]$. The $A_{1}$ receptor in rat cardiac fibroblasts participates in the regulation of extracellular adenosine levels [91]. Adenosine $A_{2 B}$ receptor stimulation has been shown to suppress collagen production by cardiac fibro-blasts, suggesting a protective effect of this receptor in myocardial fibrosis [92]. These results are consistent with the observation that $\mathrm{A}_{2 \mathrm{~B}}$ receptor stimulation prevents cardiac remodeling and protects against elevations in cardiac collagen volume and cardiac fibrosis following induction of myocardial infarction by ligation of left anterior descending coronary artery in Wistar rats, with subsequent improvement in cardiac function [93].

Modulation of metalloproteinase activity by adenosine has also been demonstrated in fibroblast-like synoviocytes, where $\mathrm{A}_{2 \mathrm{~B}}$ receptor stimulation suppresses collagenase, but not stromelysin or tissue inhibitor of metalloproteinase 1 (TIMP-1) gene expression [43]. Finally, adenosine deam-inase-deficient mice also display evidence of elevation in adenosine levels and adenosine $\mathrm{A}_{2 \mathrm{~B}}$ receptor activation in the penis. It has been suggested that this is an important mechanism for the development of priapism in these mice, and is associated with histologically demonstrable fibrosis in the corpus spongiosum and corpus cavernosum on Masson's trichrome staining [94].

\section{Conclusions}

Work in the last decade has clearly demonstrated an important role for adenosine in the pathophysiologic control of tissue fibrosis. Adenosine receptor subtypes may vary in their differential responses in the regulation of fibrosis, similar to what has been known about the 
influence of adenosine receptors in monitoring other physiologic processes such as giant cell formation. The physiologic response of each receptor in turn may be tissue specific, perhaps dependent on inciting stimuli that induce adenosine release and modulate receptor expression and function. In this respect, the heart and lung, organs constantly exposed to a vast number of antigens, may respond differently to adenosine than the skin or liver. Developments in modern receptor pharmacology may one day put this new-found knowledge to good use, and therapy for some of these hitherto untreatable fibrotic conditions may soon be on the horizon. Indeed, adenosine receptor antagonism provides a promising therapeutic strategy for the future. Adenosine $\mathrm{A}_{2 \mathrm{~A}}$ receptor antagonists have already been used for the treatment of Parkinson's disease, reducing occurrences of the onoff phenomenon, although their overall clinical benefit in Parkinson's disease has been called into question. Thus, targeting the relevant adenosine receptor may be a novel therapeutic option in the treatment of fibrotic diseases, for instance, adenosine $\mathrm{A}_{2 \mathrm{~A}}$ receptor antagonism for the treatment of dermal and hepatic fibrosis, or $\mathrm{A}_{2 \mathrm{~B}}$ receptor antagonism for the treatment of pulmonary fibrosis.

\section{Acknowledgments}

This work was supported by grants from the National Institutes of Health (AR54897 and AR56672), King Pharmaceuticals, the NYU-HHC Clinical and Translational Science Institute (UL1RR029893).

\section{References}

1. Drury AN, Szent-Gyorgi A. The physiological activity of adenine compounds with special reference to their action upon the mammalian heart. J Physiol. 1929; 68:213-37. [PubMed: 16994064]

2. Sattin A, Rall TW. The effect of adenosine and adenine nucleotides on the cyclic adenosine- $3^{\prime}, 5^{\prime}-$ phosphate content of guinea pig cerebral cortex slices. Mol Pharmacol. 1970; 6:13-23. [PubMed: 4354003]

3. Olah ME, Stiles GL. Adenosine receptor subtypes: characterization and therapeutic regulation. Ann Rev Pharmacol Toxicol. 1995; 35:581-606. [PubMed: 7598508]

4. Fredholm BB, Arslan G, Halldner L, Kull B, Schulte G, Wass-erman W. Structure and function of adenosine receptors and their genes. Naunyn Schmiedebergs Arch Pharmacol. 2000; 362(4-5):364 74. [PubMed: 11111830]

5. Montesinos, MC.; Cronstein, BN. Role of P1 receptors in inflam-mation. In: Abbracchio, MP.; Williams, M., editors. Handbook of experimental pharmacology, vol 151/II: Purinergic and pyrimid-inergic signaling II. Cardiovascular respiratory, immune, metabolic and gastrointestinal tract function. Berlin: Springer; 2001. p. 303-21.

6. Chan ESL, Fernandez P, Cronstein BN. Adenosine in inflam-matory joint diseases. Purinergic Signal. 2007; 3:145-52. [PubMed: 18404428]

7. Salmon JE, Cronstein BN. Fcgamma receptor-mediated functions in neutrophils are modulated by adenosine receptor occupancy: A1 receptors are stimulatory and A2 receptors are inhibitory. $\mathrm{J}$ Immunol. 1990; 145:2235-40. [PubMed: 2168919]

8. Londos C, Cooper DM, Wolff J. Subclasses of external adenosine receptors. Proc Natl Acad Sci USA. 1980; 77(5):2551-4. [PubMed: 6248853]

9. Montesinos MC, Gadangi P, Longaker M, Sung J, Levine J, Nilsen D, et al. Wound healing is accelerated by agonists of adenosine A2 (G alpha s-linked) receptors. J Exp Med. 1997; 186(9): 1615-20. [PubMed: 9348321]

10. Montesinos MC, Desai A, Chen JF, Yee H, Schwarzschild MA, Fink JS, et al. Adenosine promotes wound healing and mediates angiogenesis in response to tissue injury via occupancy of $\mathrm{A}(2 \mathrm{~A})$ receptors. Am J Pathol. 2002; 160(6):2009-18. [PubMed: 12057906]

11. Victor-Vega C, Desai A, Montesinos MC, Cronstein BN. Adenosine A2A receptor agonists promote more rapid wound healing than recombinant human platelet-derived growth factor (Becaplermin gel). Inflammation. 2002; 26(1):19-24. [PubMed: 11936752] 
12. Cronstein BN, Kramer SB, Weissmann G, Hirschhorn R. Adenosine: a physiological modulator of superoxide anion generation by human neutrophils. J Exp Med. 1983; 158(4):1160-77. [PubMed: 6311934]

13. Cronstein BN, Rosenstein ED, Kramer SB, Weissmann G, Hirsch-horn R. Adenosine; a physiologic modulator of superoxide anion generation by human neutrophils. Adenosine acts via an A2 receptor on human neutrophils. J Immunol. 1985; 135(2):1366-71. [PubMed: 2989364]

14. Sullivan GW, Linden J, Buster BL, Scheld WM. Neutrophil A2A adenosine receptor inhibits inflammation in a rat model of meningitis: synergy with the type IV phosphodiesterase inhibitor, rolipram. J Infect Dis. 1999; 180(5):1550-60. [PubMed: 10515815]

15. Cronstein BN, Levin RI, Belanoff J, Weissmann G, Hirschhorn R. Adenosine: an endogenous inhibitor of neutrophil-mediated injury to endothelial cells. J Clin Invest. 1986; 78:760-70. [PubMed: 3745437]

16. Rosengren S, Arfors KE, Proctor KG. Potentiation of leukotriene B4-mediated inflammatory response by the adenosine antagonist, 8-phenyl theophylline. Int J Microcirc Clin Exp. 1991; 10:345-57. [PubMed: 1663916]

17. Ohta A, Sitkovsky M. Role of G-protein-coupled adenosine receptors in downregulation of inflammation and protection from tissue damage. Nature. 2001; 414(6866):916-20. [PubMed: 11780065]

18. Okusa MD, Linden J, Macdonald T, Huang L. Selective A2A adenosine receptor activation reduces ischemia-reperfusion injury in rat kidney. Am J Physiol. 1999; 277(3 Pt 2):F404-12. [PubMed: 10484524]

19. Okusa MD, Linden J, Huang L, Rieger JM, Macdonald TL, Huynh LP. A(2A) adenosine receptormediated inhibition of renal injury and neutrophil adhesion. Am J Physiol Renal Physiol. 2000; 279(5):F809-18. [PubMed: 11053040]

20. Ross SD, Tribble CG, Linden J, Gangemi JJ, Lanpher BC, Wang AY, et al. Selective adenosineA2A activation reduces lung reperfusion injury following transplantation. J Heart Lung Transplant. 1999; 18(10):994-1002. [PubMed: 10561110]

21. McPherson JA, Barringhaus KG, Bishop GG, Sanders JM, Rieger JM, Hesselbacher SE, et al. Adenosine $\mathrm{A}(2 \mathrm{~A})$ receptor stimulation reduces inflammation and neointimal growth in a murine carotid ligation model. Arterioscler Thromb Vasc Biol. 2001; 21(5):791-6. [PubMed: 11348876]

22. Cronstein BN, Levin RI, Philips MR, Hirschhorn R, Abramson SB, Weissmann G. Neutrophil adherence to endothelium is enhanced via adenosine A1 receptors and inhibited via adenosine A2 receptors. J Immunol. 1992; 148:2201-6. [PubMed: 1347551]

23. Huang S, Apasov S, Koshiba M, Sitkovsky M. Role of A2a extracellular adenosine receptormediated signaling in adenosine-mediated inhibition of T-cell activation and expansion. Blood. 1997; 90(4):1600-10. [PubMed: 9269779]

24. Marone G, Plaut M, Lichtenstein LM. Characterization of a specific adenosine receptor on human lymphocytes. J Immunol. 1978; 121:2153-9. [PubMed: 214496]

25. Schultz LA, Kammer GM, Rudolph SA. Characterization of the human T lymphocyte adenosine receptor: comparison of normal and systemic lupus erythematosus cells. FASEB J. 1988; 2:244 50. [PubMed: 3258258]

26. Kammer GM, Birch RE, Polmar SH. Impaired immunoregulation in systemic lupus erythematosus: defective adenosine-induced suppressor T lymphocyte generation. J Immunol. 1983; 130:1706-12. [PubMed: 6220065]

27. Mandler R, Birch RE, Polmar SH, Kammer GM, Rudolph SA. Abnormal adenosine-induced immunosuppression and cAMP metabolism in T lymphocytes of patients with systemic lupus erythematosus. Proc Natl Acad Sci USA. 1982; 79:7542-6. [PubMed: 6296838]

28. Apasov SG, Koshiba M, Chused TM, Sitkovsky MV. Effects of extracellular ATP and adenosine on different thymocyte subsets. Possible role of ATP-gated channels and G protein-coupled purinergic receptor. J Immunol. 1997; 158:5095-105. [PubMed: 9164924]

29. Resta R, Hooker SW, Laurent AB, Jamshedur Rahman SM, Franklin M, Knudsen TB, et al. Insights into thymic purine metabolism and adenosine deaminase deficiency revealed by transgenic mice overexpressing ecto-5'-nucleotidase (CD73). J Clin Invest. 1997; 99(4):676-83. [PubMed: 9045870] 
30. Williams BA, Blay J, Hoskin DW. 2-Chloroadenosine stimulates granule exocytosis from mouse natural killer cells: evidence for signal transduction through a novel extracellular receptor. Exp Cell Res. 1997; 233(1):187-97. [PubMed: 9184087]

31. Hoskin DW, Reynolds T, Blay J. 2-Chloroadenosine inhibits the MHC-unrestricted cytolytic activity of anti-CD3-activated killer cells: evidence for the involvement of a non- A1/A2 cellsurface adenosine receptor. Cell Immunol. 1994; 159(1):85-93. [PubMed: 7954843]

32. Koshiba M, Rosin DL, Hayashi N, Linden J, Sitkovsky MV. Patterns of A2A extracellular adenosine receptor expression in different functional subsets of human peripheral T cells. Flow cytometry studies with anti-A2A receptor monoclonal antibodies [In Process Citation]. Mol Pharmacol. 1999; 55(3):614-24. [PubMed: 10051547]

33. Sitkovsky MV. Extracellular purines and their receptors in immunoregulation. Review of recent advances. Nippon Ika Dai-gaku Zasshi. 1998; 65(5):351-7.

34. Koshiba M, Kojima H, Huang S, Apasov S, Sitkovsky MV. Memory of extracellular adenosine A2A purinergic receptor-mediated signaling in murine T cells. J Biol Chem. 1997; 272(41): 25881-9. [PubMed: 9325320]

35. Reinstein LJ, Lichtman SN, Currin RT, Wang J, Thurman RG, Lemasters JJ, et al. Suppression of lipopolysaccharide-stimulated release of tumor necrosis factor by adenosine: evidence for A2 receptors on rat Kupffer cells. Hepatology. 1994; 19(6):1445-52. [PubMed: 8188175]

36. Hasko G, Szabo C, Nemeth ZH, Kvetan V, Pastores SM, Vizi ES. Adenosine receptor agonists differentially regulate IL-10, TNF-alpha, and nitric oxide production in RAW 264.7 macrophages and in endotoxemic mice. J Immunol. 1996; 157(10):4634-40. [PubMed: 8906843]

37. Sajjadi FG, Takabayashi K, Foster AC, Domingo RC, Firestein GS. Inhibition of TNF-alpha expression by adenosine: role of A3 adenosine receptors. J Immunol. 1996; 156(9):3435-42. [PubMed: 8617970]

38. Szabo C, Scott GS, Virag L, Egnaczyk G, Salzman AL, Shanley TP, et al. Suppression of macrophage inflammatory protein (MIP)-1alpha production and collagen-induced arthritis by adenosine receptor agonists. Br J Pharmacol. 1998; 125(2):379-87. [PubMed: 9786512]

39. Hasko G, Kuhel DG, Chen JF, Schwarzschild MA, Deitch EA, Mabley JG, et al. Adenosine inhibits IL-12 and TNF-alpha production via adenosine A2a receptor-dependent and independent mechanisms [In Process Citation]. FASEB J. 2000; 14(13):2065-74. [PubMed: 11023991]

40. Khoa ND, Montesinos MC, Reiss AB, Delano D, Awadallah N, Cronstein BN. Inflammatory cytokines regulate function and expression of adenosine $\mathrm{A}(2 \mathrm{~A})$ receptors in human monocytic THP-1 cells. J Immunol. 2001; 167(7):4026-32. [PubMed: 11564822]

41. Lukashev D, Ohta A, Apasov S, Chen JF, Sitkovsky M. Cutting edge: physiologic attenuation of proinflammatory transcription by the Gs protein-coupled A2A adenosine receptor in vivo. J Immunol. 2004; 173(1):21-4. [PubMed: 15210754]

42. Majumdar S, Aggarwal BB. Methotrexate suppresses nf-kappab activation through inhibition of ikappabalpha phosphorylation and degradation. J Immunol. 2001; 167(5):2911-20. [PubMed: 11509639]

43. Boyle DL, Sajjadi FG, Firestein GS. Inhibition of synoviocyte collagenase gene expression by adenosine receptor stimulation. Arthritis Rheum. 1996; 39:923-30. [PubMed: 8651985]

44. Bong GW, Rosengren S, Firestein GS. Spinal cord adenosine receptor stimulation in rats inhibits peripheral neutrophil accumulation. The role of $N$-methyl-D-aspartate receptors. J Clin Invest. 1996; 98:2779-85. [PubMed: 8981924]

45. Sun CX, Young HW, Molina JG, Volmer JB, Schnermann J, Blackburn MR. A protective role for the A1 adenosine receptor in adenosine-dependent pulmonary injury. J Clin Invest. 2005; 115(1): 35-43. [PubMed: 15630442]

46. Panther E, Corinti S, Idzko M, Herouy Y, Napp M, la Sala A, et al. Adenosine affects expression of membrane molecules, cytokine and chemokine release, and the T-cell stimula-tory capacity of human dendritic cells. Blood. 2003; 101(10):3985-90. [PubMed: 12446452]

47. Link AA, Kino T, Worth JA, McGuire JL, Crane ML, Chrousos GP, et al. Ligand-activation of the adenosine A2a receptors inhibits IL-12 production by human monocytes. J Immunol. 2000; 164(1):436-42. [PubMed: 10605040] 
48. Erdmann AA, Gao ZG, Jung U, Foley J, Borenstein T, Jacobson KA, et al. Activation of Th1 and Tc1 cell adenosine A2A receptors directly inhibits IL-2 secretion in vitro and IL-2-driven expansion in vivo. Blood. 2005; 105(12):4707-14. [PubMed: 15746085]

49. Bryce PJ, Dascombe MJ, Hutchinson IV. Immunomodulatory effects of pharmacological elevation of cyclic AMP in T lymphocytes proceed via a protein kinase A independent mechanism. Immunopharmacology. 1999; 41(2):139-46. [PubMed: 10102795]

50. Merrill JT, Shen C, Schreibman D, Coffey D, Zakharenko O, Fisher R, et al. Adenosine A1 receptor promotion of multinu-cleated giant cell formation by human monocytes: a mechanism for methotrexate-induced nodulosis in rheumatoid arthritis. Arthritis Rheum. 1997; 40:1308-15. [PubMed: 9214432]

51. Driver AG, Kukoly CA, Ali S, Mustafa SJ. Adenosine in bron-choalveolar lavage fluid in asthma. Am Rev Respir Dis. 1993; 148(1):91-7. [PubMed: 8317821]

52. Huszar E, Vass G, Vizi E, Csoma Z, Barat E, Molnar Vilagos G, et al. Adenosine in exhaled breath condensate in healthy volunteers and in patients with asthma. Eur Respir J. 2002; 20(6):1393-8. [PubMed: 12503694]

53. Blackburn MR, Lee CG, Young HW, Zhu Z, Chunn JL, Kang MJ, et al. Adenosine mediates IL-13-induced inflammation and remodeling in the lung and interacts in an IL-13-adenosine amplification pathway. J Clin Invest. 2003; 112(3):332-44. [PubMed: 12897202]

54. Ma B, Blackburn MR, Lee CG, Homer RJ, Liu W, Flavell RA, et al. Adenosine metabolism and murine strain-specific IL-4-induced inflammation, emphysema, and fibrosis. J Clin Invest. 2006; 116(5):1274-83. [PubMed: 16670768]

55. Volmer JB, Thompson LF, Blackburn MR. Ecto-5'-nucleotidase (CD73)-mediated adenosine production is tissue protective in a model of bleomycin-induced lung injury. J Immunol. 2006; 176(7):4449-58. [PubMed: 16547283]

56. Belperio JA, Dy M, Burdick MD, Xue YY, Li K, Elias JA, et al. Interaction of IL-13 and C10 in the pathogenesis of bleomycin-induced pulmonary fibrosis. Am J Respir Cell Mol Biol. 2002; 27(4):419-27. [PubMed: 12356575]

57. Zhu Z, Homer RJ, Wang Z, Chen Q, Geba GP, Wang J, et al. Pulmonary expression of interleukin-13 causes inflammation, mucus hypersecretion, subepithelial fibrosis, physiologic abnormalities, and eotaxin production. J Clin Invest. 1999; 103(6):779-88. [PubMed: 10079098]

58. Hancock A, Armstrong L, Gama R, Millar A. Production of interleukin 13 by alveolar macrophages from normal and fibrotic lung. Am J Respir Cell Mol Biol. 1998; 18(1):60-5. [PubMed: 9448046]

59. Chiaramonte MG, Donaldson DD, Cheever AW, Wynn TA. An IL-13 inhibitor blocks the development of hepatic fibrosis during a T-helper type 2-dominated inflammatory response. J Clin Invest. 1999; 104(6):777-85. [PubMed: 10491413]

60. Chunn JL, Molina JG, Mi T, Xia Y, Kellems RE, Blackburn MR. Adenosine-dependent pulmonary fibrosis in adenosine deami-nase-deficient mice. J Immunol. 2005; 175(3):1937-46. [PubMed: 16034138]

61. Fernandez P, Trzaska S, Wilder T, Chiriboga L, Blackburn MR, Cronstein BN, et al. Pharmacological blockade of A2A receptors prevents dermal fibrosis in a model of elevated tissue adenosine. Am J Pathol. 2008; 172(6):1675-82. [PubMed: 18467695]

62. Blackburn MR, Aldrich M, Volmer JB, Chen W, Zhong H, Kelly S, et al. The use of enzyme therapy to regulate the metabolic and phenotypic consequences of adenosine deaminase deficiency in mice. Differential impact on pulmonary and immunologic abnormalities. J Biol Chem. 2000; 275(41):32114-21. [PubMed: 10908569]

63. Chunn JL, Young HW, Banerjee SK, Colasurdo GN, Blackburn MR. Adenosine-dependent airway inflammation and hyperre-sponsiveness in partially adenosine deaminase-deficient mice. $\mathrm{J}$ Immunol. 2001; 167(8):4676-85. [PubMed: 11591798]

64. Chunn JL, Mohsenin A, Young HW, Lee CG, Elias JA, Kellems RE, et al. Partially adenosine deaminase-deficient mice develop pulmonary fibrosis in association with adenosine elevations. Am J Physiol Lung Cell Mol Physiol. 2006; 290(3):L579-87. [PubMed: 16258000] 
65. Kaczmarek E, Koziak K, Sevigny J, Siegel JB, Anrather J, Beaudoin AR, et al. Identification and characterization of CD39/vascular ATP diphosphohydrolase. J Biol Chem. 1996; 271(51):3311622. [PubMed: 8955160]

66. Picher M, Burch LH, Hirsh AJ, Spychala J, Boucher RC. Ecto 5'-nucleotidase and nonspecific alkaline phosphatase. Two AMP-hydrolyzing ectoenzymes with distinct roles in human airways. J Biol Chem. 2003; 278(15):13468-79. [PubMed: 12560324]

67. Fortuna R, Anderson HC, Carty RP, Sajdera SW. Enzymatic characterization of the matrix vesicle alkaline phosphatase isolated from bovine fetal epiphyseal cartilage. Calcif Tissue Int. 1980; 30(3):217-25. [PubMed: 6772288]

68. Zhong H, Belardinelli L, Maa T, Zeng D. Synergy between A2B adenosine receptors and hypoxia in activating human lung fibroblasts. Am J Respir Cell Mol Biol. 2005; 32(1):2-8. [PubMed: 15472138]

69. Sun CX, Zhong H, Mohsenin A, Morschl E, Chunn JL, Molina JG, et al. Role of A2B adenosine receptor signaling in adenosine-dependent pulmonary inflammation and injury. $\mathrm{J}$ Clin Invest. 2006; 116(8):2173-82. [PubMed: 16841096]

70. Morschl E, Molina JG, Volmer JB, Mohsenin A, Pero RS, Hong JS, et al. A3 adenosine receptor signaling influences pulmonary inflammation and fibrosis. Am J Respir Cell Mol Biol. 2008; 39(6):697-705. [PubMed: 18587054]

71. Chan ES, Cronstein BN. Molecular action of methotrexate in inflammatory diseases. Arthritis Res. 2002; 4(4):266-73. [PubMed: 12106498]

72. Cronstein BN. Low-dose methotrexate: a mainstay in the treatment of rheumatoid arthritis. Pharmacol Rev. 2005; 57(2):163-72. [PubMed: 15914465]

73. Nagy LE, Diamond I, Casso DJ, Franklin C, Gordon AS. Ethanol increases extracellular adenosine by inhibiting adenosine uptake via the nucleoside transporter. J Biol Chem. 1990; 265(4):1946-51. [PubMed: 2298733]

74. Puig JG, Fox IH. Ethanol-induced activation of adenine nucleotide turnover. Evidence for a role of acetate. J Clin Invest. 1984; 74(3):936-41. [PubMed: 6470146]

75. El Yacoubi M, Ledent C, Parmentier M, Costentin J, Vaugeois JM. Caffeine reduces hypnotic effects of alcohol through adenosine A2A receptor blockade. Neuropharmacology. 2003; 45(7): 977-85. [PubMed: 14573390]

76. Klatsky AL, Armstrong MA. Alcohol, smoking, coffee, and cirrhosis. Am J Epidemiol. 1992; 136(10):1248-57. [PubMed: 1476147]

77. Klatsky AL, Armstrong MA, Friedman GD. Coffee, tea, and mortality. Ann Epidemiol. 1993; 3(4): 375-81. [PubMed: 8275213]

78. Jiao J, Friedman SL, Aloman C. Hepatic fibrosis. Curr Opin Gastroenterol. 2009; 25(3):223-9. [PubMed: 19396960]

79. Friedman SL. Hepatic fibrosis-overview. Toxicology. 2008; 254(3):120-9. [PubMed: 18662740]

80. Friedman SL. Mechanisms of hepatic fibrogenesis. Gastroenter-ology. 2008; 134(6):1655-69.

81. Friedman SL. Hepatic stellate cells: protean, multifunctional, and enigmatic cells of the liver. Physiol Rev. 2008; 88(1):125-72. [PubMed: 18195085]

82. Chan ES, Montesinos MC, Fernandez P, Desai A, Delano DL, Yee H, et al. Adenosine A(2A) receptors play a role in the pathogenesis of hepatic cirrhosis. Br J Pharmacol. 2006; 148(8):114455. [PubMed: 16783407]

83. Hashmi AZ, Hakim W, Kruglov EA, Watanabe A, Watkins W, Dranoff JA, et al. Adenosine inhibits cytosolic calcium signals and chemotaxis in hepatic stellate cells. Am J Physiol Gastrointest Liver Physiol. 2007; 292(1):G395-401.

84. Sohail MA, Hashmi AZ, Hakim W, Watanabe A, Zipprich A, Groszmann RJ, et al. Adenosine induces loss of actin stress fibers and inhibits contraction in hepatic stellate cells via Rho inhibition. Hepatology. 2009; 49(1):185-94. [PubMed: 18844235]

85. Hernandez-Munoz R, Diaz-Munoz M, Suarez-Cuenca JA, Trejo-Solis C, Lopez V, SanchezSevilla L, et al. Adenosine reverses a preestablished CCl4-induced micronodular cirrhosis through enhancing collagenolytic activity and stimulating hepatocyte cell proliferation in rats. Hepatology. 2001; 34(4 Pt 1):677-87. [PubMed: 11584363] 
86. Che J, Chan ES, Cronstein BN. Adenosine A2A receptor occupancy stimulates collagen expression by hepatic stellate cells via pathways involving protein kinase A, Src, and extracellular signalregulated kinases $1 / 2$ signaling cascade or p38 mitogen-activated protein kinase signaling pathway. Mol Pharmacol. 2007; 72(6):1626-36. [PubMed: 17872970]

87. Chan ES, Fernandez P, Merchant AA, Montesinos MC, Trzaska S, Desai A, et al. Adenosine A2A receptors in diffuse dermal fibrosis: pathogenic role in human dermal fibroblasts and in a murine model of scleroderma. Arthritis Rheum. 2006; 54(8):2632-42. [PubMed: 16871530]

88. Katebi M, Fernandez P, Chan ES, Cronstein BN. Adenosine A2A receptor blockade or deletion diminishes fibrocyte accumulation in the skin in a murine model of scleroderma, bleomycininduced fibrosis. Inflammation. 2008; 31(5):299-303. [PubMed: 18709547]

89. Dubey RK, Gillespie DG, Mi Z, Jackson EK. Exogenous and endogenous adenosine inhibits fetal calf serum-induced growth of rat cardiac fibroblasts: role of A2B receptors. Circulation. 1997; 96(8):2656-66. [PubMed: 9355907]

90. Dubey RK, Gillespie DG, Shue H, Jackson EK. A(2B) receptors mediate antimitogenesis in vascular smooth muscle cells. Hypertension. 2000; 35(1 Pt 2):267-72. [PubMed: 10642309]

91. Andresen BT, Gillespie DG, Mi Z, Dubey RK, Jackson EK. Role of adenosine A(1) receptors in modulating extracellular adenosine levels. J Pharmacol Exp Ther. 1999; 291(1):76-80. [PubMed: 10490889]

92. Dubey RK, Gillespie DG, Jackson EK. Adenosine inhibits collagen and protein synthesis in cardiac fibroblasts: role of A2B receptors. Hypertension. 1998; 31(4):943-8. [PubMed: 9535419]

93. Wakeno M, Minamino T, Seguchi O, Okazaki H, Tsukamoto O, Okada K, et al. Long-term stimulation of adenosine A2b receptors begun after myocardial infarction prevents cardiac remodeling in rats. Circulation. 2006; 114(18):1923-32. [PubMed: 17043167]

94. Mi T, Abbasi S, Zhang H, Uray K, Chunn JL, Xia LW, et al. Excess adenosine in murine penile erectile tissues contributes to priapism via A2B adenosine receptor signaling. J Clin Invest. 2008; 118(4):1491-501. [PubMed: 18340377] 


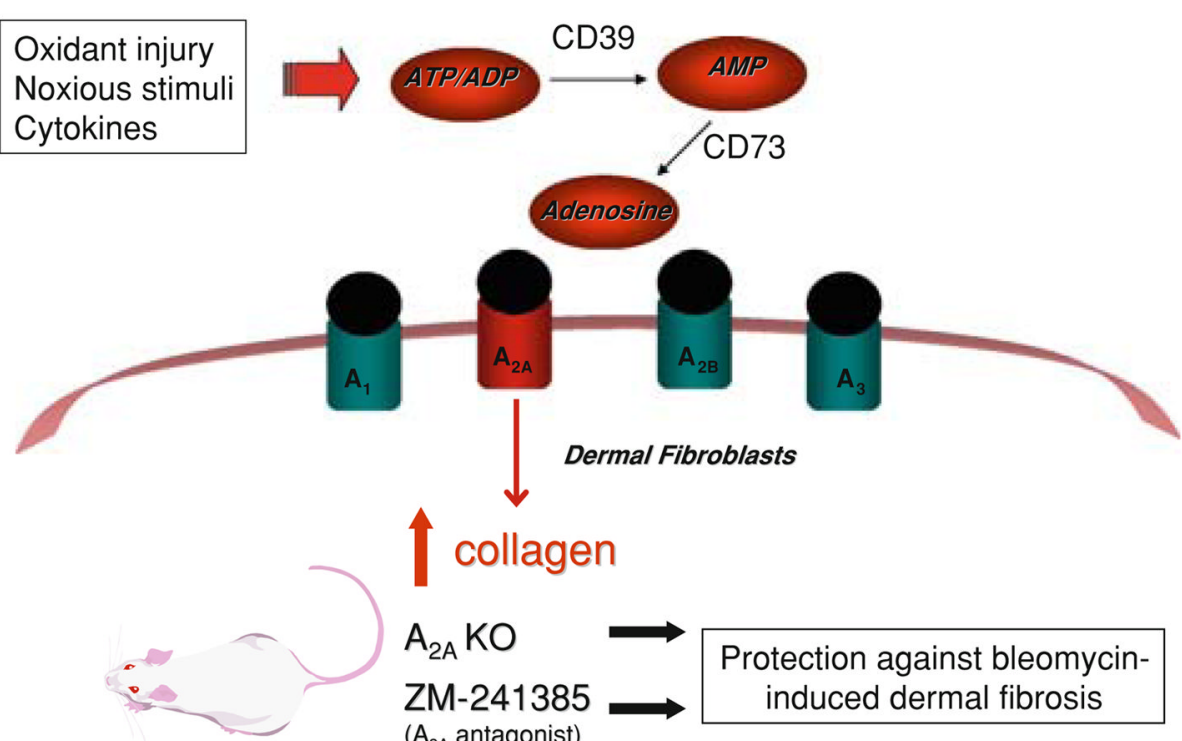

Fig 1.

Schematic representation of proposed mechanism of involvement of adenosine in dermal fibrosis 